\title{
La différence incarnée
}

Remarques sur le traitement du corps animal en boucherie

Noëlie Vialles

\section{CpenEdition}

\section{Journals}

Édition électronique

URL : https://journals.openedition.org/tc/784

DOI : $10.4000 /$ tc. 784

ISSN : 1952-420X

Éditeur

Éditions de l'EHESS

\section{Édition imprimée}

Date de publication : 1 février 1990

ISSN : 0248-6016

\section{Référence électronique}

Noëlie Vialles, «La différence incarnée », Techniques \& Culture [En ligne], 13 | 1990, mis en ligne le 16 janvier 2006, consulté le 29 septembre 2022. URL : http://journals.openedition.org/tc/784 ; DOI : https://doi.org/10.4000/tc.784

Ce document a été généré automatiquement le 29 septembre 2022.

Tous droits réservés 


\section{La différence incarnée}

Remarques sur le traitement du corps animal en boucherie

Noëlie Vialles 